\title{
Pressurization Analysis of Containers in the SAFKEG 3940A Package in KAMS (U)
}

\author{
Stephen H. Malene \\ George B. Rawls \\ Savannah River Technology Center \\ Strategic Materials Technology Department \\ Materials Technology Section
}

June 2003

Patent Status

This internal management report is being transmitted

without DOE patent clearance, and no further

dissemination or publication shall be made of the report

without prior approval of the DOE-SR patent counsel.

\section{Westinghouse Savannah River Company Savannah River Site Aiken, SC 29808}

This document was prepared in connection with work done under Contract No. DE-AC09-96SR18500 with the U. S. Department of Energy 
This document was prepared in conjunction with work accomplished under Contract No. DE-AC09-96SR18500 with the U. S. Department of Energy.

\section{DISCLAIMER}

This report was prepared as an account of work sponsored by an agency of the United States Government. Neither the United States Government nor any agency thereof, nor any of their employees, makes any warranty, express or implied, or assumes any legal liability or responsibility for the accuracy, completeness, or usefulness of any information, apparatus, product or process disclosed, or represents that its use would not infringe privately owned rights. Reference herein to any specific commercial product, process or service by trade name, trademark, manufacturer, or otherwise does not necessarily constitute or imply its endorsement, recommendation, or favoring by the United States Government or any agency thereof. The views and opinions of authors expressed herein do not necessarily state or reflect those of the United States Government or any agency thereof.

This report has been reproduced directly from the best available copy.

Available for sale to the public, in paper, from: U.S. Department of Commerce, National Technical Information Service, 5285 Port Royal Road, Springfield, VA 22161, phone: (800) 553-6847, fax: (703) 605-6900

email: orders@ntis.fedworld.gov

online ordering: http://www.ntis.gov/help/index.asp

Available electronically at http://www.osti.gov/bridge

Available for a processing fee to U.S. Department of Energy and its contractors, in paper, from: U.S. Department of Energy, Office of Scientific and Technical Information, P.O. Box 62, Oak Ridge, TN 37831-0062,

phone: (865)576-8401,

fax: (865)576-5728

email: $\underline{\text { reports@ adonis.osti.gov }}$ 


\section{TABLE OF CONTENTS}

\section{Page}

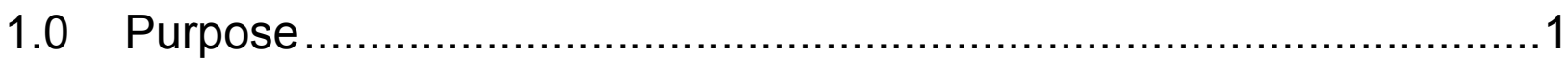

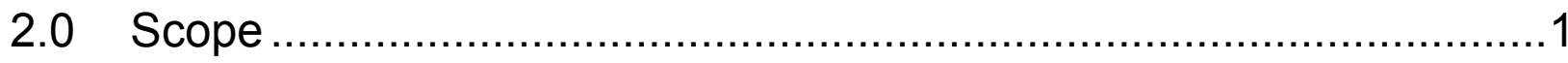

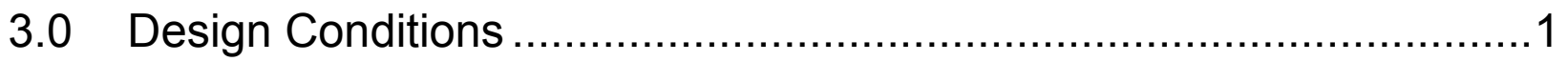

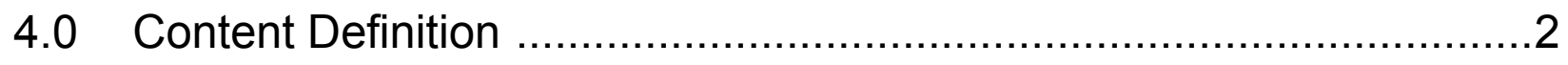

5.0 Potential Pressurization Mechanisms ............................................

5.1 Pressure Buildup due to Internal and External Heating ................ 4

5.2 Gas Generation from Radiolysis .............................................

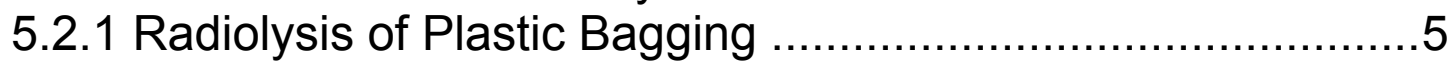

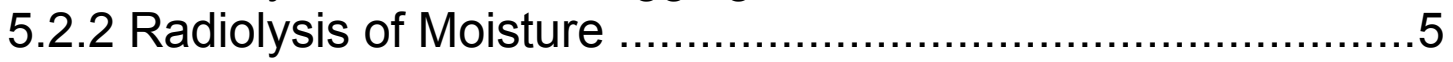

5.3 Gas Generation from Helium Production ....................................

5.4 Total Pressure Rise in 3942 Vessel ...................................

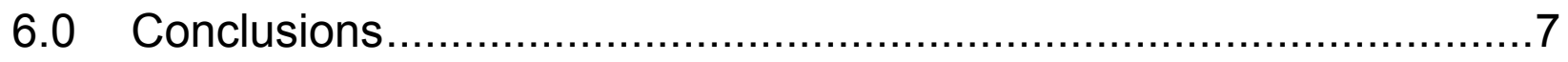

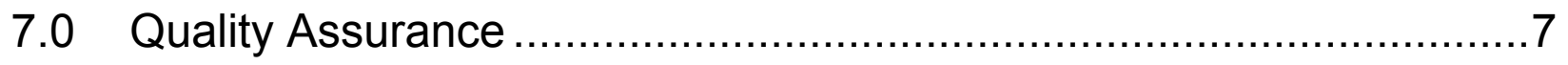

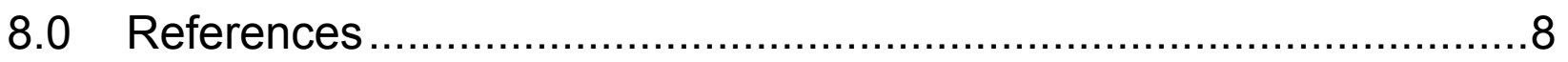




\subsection{Purpose}

This report evaluates the pressure capacity of the SAFKEG 3940A shipping package for storage in the K- Area Materials Storage Facility (KAMS). Bounding internal pressures are determined and compared to calculated maximum allowable pressures.

\subsection{SCOPE}

Plutonium and plutonium oxide within the standard storage cans as shipped from the Hanford Site in the SAFKEG 3940A shipping package is considered in this evaluation. These drums will be received and stored for $10+$ years in the KAMS Facility at SRS. An initial transit time of one year was considered in the design of the SAFKEG. An additional year is added to the transportation time to address additional transit at the end of storage. Therefore a two-year transit time period is considered in addition to the proposed $10+$ storage period bringing the total time for the material to be in the SAFKEG package to $12+$ years.

The scope of this report is to determine bounding maximum pressures in the SAFKEG 3940A package due to heating and gas generation mechanisms over the 12+ year time period. The bounding pressures are compared to allowable capacities for the containers.

The external conditions provided below are considered in this report.

Normal Conditions of Transportation (NCT)

Hypothetical Transportation Accident Conditions (HAC)

\subsection{Design Conditions}

The SAFKEG was designed and analyzed at Los Alamos National Laboratory for carrying Type-B materials across the DOE complex and meets the requirements of 10CFR71 [1].

The containment vessels within the SAFKEG 3940A package are:

3942 Inner Containment Vessel (contains the 3013 container)

3941 Outer Containment Vessel (contains the 3942). 
The design pressure for the two vessels for both the NCT and the HAC is 8 bar abs/116 psia (7 bar guage/101.5 psig). The corresponding design temperatures are $147^{\circ} \mathrm{C}$ $\left(297^{\circ} \mathrm{F}\right)$ for the $\mathrm{NCT}$ and $200^{\circ} \mathrm{C}\left(392^{\circ} \mathrm{F}\right)$ for the HAC.

An evaluation to determine the collapse pressure [3] of the SAFKEG inner and outer containment vessels was performed to determine their capacity beyond code allowable limits. The limiting capacities provided for a temperature of $400^{\circ} \mathrm{F}$ (Max Design Temperature $392^{\circ} \mathrm{F}$ ) are 1060 psig for the inner vessel and 910 psig for the outer vessel. Both these pressures represent the failure of the O-ring seal. The vessels are still in the elastic range of the material curves for these pressures. The calculated burst pressures at $400^{\circ} \mathrm{F}$ are 5040 psig for the inner vessel and 4340 psig for the outer vessel.

All the material to be stored in the SAFKEG in the KAMS facility will be contained in a 3013 container. The 3013 container consists as a minimum of two individually sealed and nested containers to isolate the stored materials from the environment. The outer container provides the pressure boundary to prevent release of contents. The inner container provides an additional isolation boundary as well as an internal pressure indicator. DOE Standard "Stabilization, Packaging, and Storage of Plutonium-Bearing Materials" [4] states that the pressure buildup in the inner 3013 container is expected to yield internal pressures less than $790 \mathrm{kPa}$ (100 psig) from all known pressurization mechanisms. It is further stipulated that the inner container allows for a non-destructive indication of a buildup of internal pressure at less than $790 \mathrm{kPa}(100 \mathrm{psig})$. The design pressure of the 3013 outer container is $4920.7 \mathrm{kPa}$ (699 psig) and is designated "Safety Class". The results of this analysis do not credit the capacity of the 3013 container.

\subsection{Contents Definition}

The permitted contents are defined in the Safety Analysis Report for Packaging SAFKEG 3940A, [1], in which the radioactive material, non-radioactive material and packing materials and configurations are specified. In the KAMS facility only the 3013 Storage Container will be in the SAFKEG. $\equiv$ excerpt from the SARP [1] for the definition of the Storage Can is provided below. 


\section{Table 1.1E Definitions (Excerpt from the SARP [1])}

\begin{tabular}{|c|l|}
\hline Storage Can & $\begin{array}{l}\text { The contents of the Storage Can shall be conditioned as defined below. } \\
\text { The "Storage Can" is an assembly of steel cans having a total mass of } \\
\text { steel limited to 7.5kg and has the following containers: }\end{array}$ \\
\hline $\begin{array}{c}\text { Convenience } \\
\text { Container }\end{array}$ & $\begin{array}{l}\text { This is the innermost can and may be a food pack can having a } \\
\text { crimp/rolled lid, or a can having either a push fit lid closed with plastic } \\
\text { tape or a welded lid. These cans may be tin-plated mild steel or stainless } \\
\text { steel and shall not have any organic coating or other organic liner } \\
\text { associated with the can }\end{array}$ \\
\hline $\begin{array}{c}\text { Inner } \\
\text { Container }\end{array}$ & This is a sealed (welded) wall stainless steel inner can \\
\hline $\begin{array}{c}\text { Outer } \\
\text { Container }\end{array}$ & This is a sealed (welded) wall stainless steel outer can \\
\hline
\end{tabular}

In this evaluation only the Plutonium ( $\mathrm{Pu}$ ) metal and oxide are considered to be in the 3013 storage can. The maximum mass of Pu metal in the 3013 container is $4500 \mathrm{~g}$. In the original analysis for the SAFKEG as documented in the SARP it was assumed that an oxide coating was present on the surface of the metal. The amount of moisture contained in the oxide on the metal surface was assumed to be $5 \mathrm{~g}$ [1]. The same assumption is used in this report. The amount of $\mathrm{Pu}$ oxide in the container is limited to $5000 \mathrm{~g}$ with a maximum moisture content of $25 \mathrm{~g}$ [1]. These moisture contents are use to calculate the amount of hydrogen available for pressure build up from radiolysis of the moisture.

\subsection{Potential Pressurization Mechanisms}

The contents of the overall package assembly 3940A may not contain liquids. The contents may be in dry solid or powder forms only. There are three sources for the potential buildup of pressure in the inner containment vessel (3942):

- Expansion potential of enclosed gas due to internal and external heating

- Gas generation due to radiological decomposition of moisture or organic materials

- Gas generation due to helium production from alpha decay emission 


\subsection{Pressure Buildup due to Internal and External Heating}

The two heat sources of concern are due to internal source heating and external environmental heating. The material is to be stored in 3013 containers inside 3940A package containers. The SAFKEG 3940A package is the collective term for the two nested containment vessels, both within an external drum that comprise the 3940A. The design of the SAFKEG is based on the transportation conditions. These include both the Normal Conditions of Transportation and the Hypothetical Transportation Accident Conditions. The thermal analysis performed to support the use of SAFKEG in the KAMS facility the transportation conditions applied in the original design of the SAFKEG as documented in the SARP [1].

The results of the calculations for the container pressure due to contents heating for NCT and HAC for the two vessels are presented in Table 1. These results are extracted directly from the SARP [1\&2]. The analysis from the SARP used a $30 \mathrm{~W}$ input in the calculation for the temperature rises provided below. The initial pressure used in the calculation was 1 bar; therefore, the maximum pressure rise is numerically equal to the ratio of final pressure to initial pressure and can be used to calculate the pressure increase from temperature for any initial pressure.

Table 1: Maximum Possible 3940A Container Pressures due to Internal Contents Heating

\begin{tabular}{|c|c|c|c|c|}
\hline \multirow[b]{2}{*}{ Condition } & \multicolumn{2}{|c|}{ NCT } & \multicolumn{2}{|c|}{$\mathrm{HAC}$} \\
\hline & 3942 (Inner) & 3941 (Outer) & 3942 (Inner) & 3941 (Outer) \\
\hline $\begin{array}{c}\text { Initial } \\
\text { Temperature }\end{array}$ & $20{ }^{0} \mathrm{C}\left(68{ }^{0} \mathrm{~F}\right)$ & $20{ }^{0} \mathrm{C}\left(68{ }^{0} \mathrm{~F}\right)$ & $20{ }^{0} \mathrm{C}\left(68{ }^{0} \mathrm{~F}\right)$ & $20{ }^{0} \mathrm{C}\left(68{ }^{0} \mathrm{~F}\right)$ \\
\hline $\begin{array}{c}\text { Maximum } \\
\text { Temperature }\end{array}$ & $147^{\circ} \mathrm{C}\left(297^{\circ} \mathrm{F}\right)$ & $118^{\circ} \mathrm{C}\left(244^{\circ} \mathrm{F}\right)$ & $200{ }^{\circ} \mathrm{C}\left(392{ }^{\circ} \mathrm{F}\right)$ & $171^{\circ} \mathrm{C}\left(340^{\circ} \mathrm{F}\right)$ \\
\hline $\begin{array}{l}\text { Maximum } \\
\text { Pressure }^{*}\end{array}$ & 1.43 bar abs & 1.33 bar abs & 1.61 bar abs & 1.52 bar abs \\
\hline
\end{tabular}




\subsection{Gas Generation from Radiolysis}

Review of data in the SARP shows that two mechanisms exist for pressure buildup due to radiolysis. These include radiolysis of plastics inside the container and radiolysis of moisture in the container. Each of these mechanisms is addressed in this report.

\subsubsection{Radiolysis of Plastic Bagging}

The calculations for the original SAFKEG design investigated the gas generation of the plastic bagging in the products can. With the advent of the bagless transfer systems plastic bags are no longer a normal part of the production canisters. The Table 1.1E excerpt, above, state that plastic tape is allowed on the convenience can lid. The calculations performed in [1] show the pressure buildup resulting from radiolysis of plastic in the container are negligible. Even though this evaluation addresses only the 3013 container in the 3942 vessel these results are presented to address any possible concerns over gas generation from the O-ring seals in the primary and secondary containers.

\subsubsection{Radiolysis of Moisture}

The potential pressure rise in the package 3940A ultimately would come from gas generation from moisture mixed with $\mathrm{Pu}$ samples within the storage cans inside the inner containment vessel 3942 . The cavity of the 3942 vessel is $5000 \mathrm{~cm}^{3}$. The free volume in the 3942 vessel is $3178 \mathrm{~cm}^{3}$ with Pu oxide contents and $783 \mathrm{~cm}^{3}$ with Pu metal contents [2]. The mechanism of hydrogen generation is radiolysis through the absorption of alpha particles in the moisture. A maximum loading condition of $0.5 \mathrm{wt} \%(25 \mathrm{~g})$ moisture is assumed for the plutonium oxide materials. The maximum available moisture on the surface of the Pu metal is $5 \mathrm{~g}$ [2]. The original calculations addressing radiolysis determined the gas generation rate. The generation rate was then used to determine the total volume of gas generated over the 1 year transit time. Expanding this method to 12 years provides an unrealistic result. In this report, the total amount of hydrogen available in the moisture is assumed to be released into the free volume of the container and the resulting pressure rise is calculated. The increase in gas volume for the $\mathrm{Pu}$ metal storage case is $6200 \mathrm{~cm}^{3}$ at STP and the increase in volume for the Pu oxide case is $31400 \mathrm{~cm}^{3}$ at STP. 


\subsection{Gas Generation from Helium Production}

The mechanism for helium generation from radioactive isotopes and their daughter products is by periodic spontaneous emission of alpha particles from the atomic nuclei of the decaying elements. The bounding gas volume for helium for both the Pu metal storage case and the Pu oxide case is $704 \mathrm{~cm}^{3}$ at STP. The helium generation value is taken for Reference 1 and is for fuel grade Pu over a 30 year time period.

\subsection{Total Pressure Rise in 3942 Vessel}

The bounding pressure rise in the 3941 and 3942 vessels are provided in Table 2 for the case of Pu metal in the vessels. Table 3 provides the bounding pressures for Pu oxide in the vessels. These values address gas generation from the radiolysis of moisture which produces hydrogen, and the helium generation from alpha decay emissions. The gas generation produces a baseline pressure level in the container that varies with temperature. The maximum pressure ratios from Table 1 are then applied to calculate the bounding pressure level in the 3941 and 3942 vessels. The assumption made in calculating the pressure rise in the 3941 vessel is that the inner vessel 3942 will not leak. This assumption is confirmed in the conclusion.

Table 2. Bounding Pressures for Pu Metal in Containers

\begin{tabular}{|c|c|c|c|c|}
\hline \multirow{2}{*}{ Condition } & \multicolumn{2}{|c|}{ NCT } & \multicolumn{2}{c|}{ HAC } \\
\cline { 2 - 5 } & 3942 (Inner) & 3941 (Outer) & 3942 (Inner) & 3941 (Outer) \\
\hline $\begin{array}{c}\text { Maximum } \\
\text { Temperature }\end{array}$ & $147^{\circ} \mathrm{C}\left(297{ }^{\circ} \mathrm{F}\right)$ & $118^{\circ} \mathrm{C}\left(244^{\circ} \mathrm{F}\right)$ & $200{ }^{\circ} \mathrm{C}\left(392{ }^{\circ} \mathrm{F}\right)$ & $171^{0} \mathrm{C}\left(340{ }^{0} \mathrm{~F}\right)$ \\
\hline $\begin{array}{c}\text { Pressure Ratio } \\
\text { due to Heating }\end{array}$ & 1.43 & 1.33 & 1.61 & 1.52 \\
\hline $\begin{array}{c}\text { Pressure due to } \\
\text { Gas Generation }\end{array}$ & 9.94 bar abs & None & 9.94 bar abs & None \\
\hline $\begin{array}{c}\text { Bounding } \\
\text { Pressure }\end{array}$ & $\begin{array}{c}14.22 \text { bar abs } \\
(192 \text { psig) }\end{array}$ & $\begin{array}{c}1.33 \text { bar abs } \\
(4.6 \text { psig) }\end{array}$ & $\begin{array}{c}16 \text { bar abs } \\
(218.0 \text { psig) }\end{array}$ & $\begin{array}{c}1.52 \text { bar abs } \\
(7.3 \text { psig })\end{array}$ \\
\hline
\end{tabular}


Table 3. Bounding Pressures for Pu Oxide in Containers

\begin{tabular}{|c|c|c|c|c|}
\hline \multirow[b]{2}{*}{ Condition } & \multicolumn{2}{|c|}{ NCT } & \multicolumn{2}{|c|}{ HAC } \\
\hline & 3942 (Inner) & 3941 (Outer) & 3942 (Inner) & 3941 (Outer) \\
\hline $\begin{array}{l}\text { Maximum } \\
\text { Temperature }\end{array}$ & $147^{\circ} \mathrm{C}\left(297^{\circ} \mathrm{F}\right)$ & $118^{\circ} \mathrm{C}\left(244^{\circ} \mathrm{F}\right)$ & $200{ }^{\circ} \mathrm{C}\left(392{ }^{\circ} \mathrm{F}\right)$ & $171^{\circ} \mathrm{C}\left(340^{\circ} \mathrm{F}\right)$ \\
\hline $\begin{array}{l}\text { Pressure Ratio } \\
\text { due to Heating }\end{array}$ & 1.43 & 1.33 & 1.61 & 1.52 \\
\hline $\begin{array}{l}\text { Pressure due to } \\
\text { Gas Generation }\end{array}$ & 11.3 bar abs & None & 11.3 bar abs & None \\
\hline $\begin{array}{l}\text { Bounding } \\
\text { Pressure }\end{array}$ & $\begin{array}{c}16.1 \text { bar abs } \\
\text { (219 psig) }\end{array}$ & $\begin{array}{c}1.33 \text { bar abs } \\
\text { (4.6 psig) }\end{array}$ & $\begin{array}{c}18.1 \text { bar abs } \\
\text { (248 psig) }\end{array}$ & $\begin{array}{c}\text { 1.52 bar abs } \\
(7.3 \text { psig) }\end{array}$ \\
\hline
\end{tabular}

\subsection{Conclusions}

The bounding pressure in the SAFKEG container of 248 psig occurs in the 3942 vessel under the HAC at the end of the 12 year storage and transport period of the KAMS project. This pressure is well below the allowable pressure of 1060 psig for the inner vessel. The assumption that the inner vessel will not leak is also justified since the allowable pressure represents the loading where the O-ring seal would fail. If leakage to the outer vessel were to occur, the allowable pressure capacity of the 3941 container is 910 psig. If leakage into the outer vessel were to occur the pressure would be reduced as the gas expanded into a larger volume. The allowable capacity values provide a margin against leakage of 3.3 on the inner vessel and a margin against leakage greater than 2.7 for the outer vessel. These pressure loads do not challenge the structural integrity of the vessels. The vessels still have elastic behavior at these pressure levels.

\subsection{Quality Assurance}

The preparation of this technical work and its documentation were performed as specified in the WSRC E7 Manual, procedure 3.60. Internal technical review of this report is governed by the WSRC E7 Manual, procedure 2.40. 


\subsection{References}

1) Safety Analysis Report for Packaging (SARP), LAUR-01-2081, SAFKEG 3940A (September 2002, draft)

2) General Report: SAFKEG 3940A, "Pressure Analysis in the Containment Vessels for Different Material Forms", GR-034, Rev. 2, supplemental to LAUR01-2081.

3) "Pressure Capabilities of SAFKEG Inner and Outer Containment Vessels (U)", Calculation Number T-CLC-K-00193, Savannah River Site, August 2002.

4) DOE-STD-3013-200, "Stabilization, Packaging, and Storage of PlutoniumBearing Materials," Section A.6.2.1, paragraph 4, September 2000

5) Calculation M-CLC-K-0660, Rev 0, Thermal Analysis of SAFKEG Package for KAMS Storage, June 2003. 